\title{
Influence of Risk Perception and Trust in Government on Vaccination in Indonesia
}

Rakhmaditya Dewi Noorrizki*, Mochammad Sa'id, Angga Yuni Mantara, M. Azhar Nabil Hamami, and Muhammad lqubal Fakhrul Firdaus

Department of Psychology, Faculty of Psychology, Universitas Negeri Malang, Indonesia

\section{ORCID}

https://orcid.org/0000-0002-8149-4406,

https://orcid.org/0000-0003-2418-5110, https://orcid.org/0000-0003-2940-9953

\begin{abstract}
The objective of this study was to examine the impact of the perception of risk and of trust in the government on people's decision to get vaccinated. 329 people from all over Indonesia participated. The research instrument used was the scale of risk perception, scale of trust in the government and scale of vaccination. The scales were distributed online via social media for 10 days in June. Pearson correlation was used to analyze the data on the correlations between risk perception and vaccination and between trust in government and vaccination. There was a significant correlation between risk perception and vaccination ( $r=0.361 ; p<0.05)$. Likewise, there was a correlation between trust in government and vaccination ( $r=0.436 ; p<0.05)$. A multiple correlation test was used to test the correlation simultaneously resulting in a correlation coefficient of 0.511 ( $p<0.05$ ) meaning that there was a simultaneous correlation between risk perception and trust in the government in the decision to vaccinate.
\end{abstract}

Corresponding Author: Rakhmaditya Dewi Noorrizki; email: rakhma-

ditya.dewi.fppsi@um.ac.id

Dates

Published 28 January 2022

Publishing services provided by Knowledge E

(c) Rakhmaditya Dewi Noorrizki et al. This article is distributed under the terms of the Commons Attribution License, which permits unrestricted use and redistribution provided that the original author and source are credited.

Selection and Peer-review unde the responsibility of the ICoPsy Conference Committee.

G OPEN ACCESS
Keywords: risk perception, trust in government, vaccination taking, Indonesia

\section{Introduction}

Unfortunately since it first appeared in Indonesia [1]. Since then, 1,341,341 positive cases have been recorded and 36,166 people have died [2]. The number of cases in Indonesia is relatively high in the Southeast Asian Region [3]. To reduce the spread and impact of Covid-19, the Government of Indonesia has implemented a number of ways, for example limiting residents' activities (PSBB, PPKM, etc.), implementing a healthy lifestyle (5M movement; wearing masks, washing hands with soap and running water, maintaining distance, staying away from crowds), and limiting mobilization and interaction) and the last resort was developing vaccines.

Regarding vaccines, since early 2021, the government has started administering vaccines to health workers and health support personnel [4] The public's response to the administration of the Covid-19 vaccine that has been scheduled by the government 
is very diverse. Based on a survey conducted by WHO [5] in collaboration with the Ministry of Health, UNICEF, and NITAG (The National Immunization Technical Advisory Group) found that $64 \%$ of Indonesians responded positively to the COVID-19 vaccination. Although more than $60 \%$ of Indonesians responded positively to the administration of the vaccine, there were still $8 \%$ who refused the vaccine and $37 \%$ who had doubts about the vaccine. The background factors depend more on the results of vaccine trials, side effects of vaccines, distrust of the existence of the COVID-19 virus, even believing that COVID-19 is the result of government propaganda WHO[5]. Based on several studies, factors that influence individuals to receive new vaccines include: knowledge [6][7], risk perception [7-9] trust in institutions which include government, and health providers $[6,8,10]$ and health motivation $[7,9]$.

Risk perception is a belief about the potential for harm or the possibility of loss in the face of a threat. In this study, the threat in question is the Covid-19 pandemic. Based on research by (Suhanti et al., [11]) it was found that $42.7 \%$ of the study subjects perceived themselves to be at moderate risk, $26.3 \%$ at low risk, and $7.3 \%$ at high risk. Risk perception is a factor behind individuals in vaccinating $[7,9,12]$.

In addition to the perception of risk, another factor that influences decision making on vaccines is trust in the government. Trust in the government in promoting vaccines and trust in providing information about the safety of the vaccine are the most powerful factors influencing people's decision to vaccinate [13].

Many studies on decision making for vaccines have been carried out with the subject of parents taking vaccines for their children [9, 14, 16-19], research on the decision to receive the vaccine for the subject himself is still very rare. So based on the description of the problem above, the researcher wants to conduct a study to see the relationship between the risk perception variable and trust in the government towards the decision to vaccinate.

\section{Hypotheses}

The hypotheses proposed in this study are the hypotheses major and hypotheses minor. The major hypothesis in this study is that there is a simultaneous relationship between perceived risk and trust in the government in the decision to vaccination taking. While the minor hypothesis 1 is that there is a correlation between risk perception and decision making to vaccinate. Minor hypothesis 2 is that there is a correlation between trust in the government and the decision to vaccinate. 


\section{Method}

This study uses a positivistic quantitative approach. The research design used is a correlational research design. The measuring instrument in this study was 3 scales of risk perception, trust in the government and vaccine decision making. The risk perception scale is adapted from the COVID-19 risk perception scale Dryhurst dkk. [20], This scale measures three aspects of risk perception, namely cognitive, affective and temporal spatial aspects. The original scale was translated-backtranslate then distributed to the test subjects. The results of the validity test using CFA showed that the Risk perception scale was valid as many as 5 items with a score range of .515-.775 with reliability $\alpha .752$. the scale of trust in the government, is an adaptation of the scale of trust in the government owned by van der Weerd dkk. [12]. The scale of trust in the government measures the level of public trust in the government regarding the provision of information related to Covid-19, the ability to overcome the pandemic and general crisis management. This scale is also translated backtranslate and then distributed to the test subjects. The Trust of government scale is valid as many as 5 items with a score range of .722-.839 and reliability $\alpha .896$. the last scale is the decision-making scale for vaccines, adapting and modifying the vaccine decision-making scale developed by [21]. This scale consists of measuring six attributes, namely vaccine effectiveness, burden of vaccine-preventable disease, vaccination accessibility, frequency of side effects, population level vaccination coverage and local vaccination coverage between family and friends. score .537-.847 and reliability $\alpha .921$

A total of 329 participants (103 men and 226 women) were involved in data collection conducted online via google forms distributed via social media (whatsapp, Instagram, twitter) between 15 June 2021 to 25 June 2021. The average age of the subjects was 27.91 years with an age range of 15-70 years. The distribution of the latest education is as follows: SMP/MTs/sederajar $(n=2)$, high school/smk/ma/equivalent $(n=187)$, diploma I/II/III ( $n=12)$, bachelor/Diploma IV ( $n=101)$, master/profession $(n=26)$, doctoral $(n=1)$

\section{Result and Discussion}

\subsection{Result}

The author categorizes the three variables, which can be seen in table 1 
TABLE 1: Categorization of subject at all variables.

\begin{tabular}{l|l|l|l} 
& $\begin{array}{l}\text { Risk } \\
\text { perception }\end{array}$ & $\begin{array}{l}\text { Trust } \\
\text { Goverment }\end{array}$ & $\begin{array}{c}\text { of Vaccine } \\
\text { acceptance }\end{array}$ \\
\hline low & $1.2 \%$ & $2.1 \%$ & $2.7 \%$ \\
\hline middle & $2.1 \%$ & $10.9 \%$ & $4.9 \%$ \\
\hline high & $96.7 \%$ & $86.9 \%$ & $92.4 \%$ \\
\hline Total & $100 \%$ & $100 \%$ & $100 \%$
\end{tabular}

Normality test using Kolmogorov Smirnov showed that the data was normally distributed with $\alpha=.082$. The linearity test with showed $F=.874(p=.638)$ for the risk perception and vaccine acceptance variables showed that both variables were linear. Meanwhile, for the trust of government and vaccine acceptance variables, the linearity test resulted in a value of $F=1.740(p=.035)$ meaning that the two variables were not linear, and then the correlation between the two would be tested using a nonparametric correlation test.

The result of Pearson's product moment correlation analysis between risk perception and vaccine-taking decision making resulted in a correlation coefficient $(r)$ of .361 with a significance level of $p=0.000(p<0.01)$. This shows that there is a very significant positive correlation between the perception of risk and the decision to vaccinate. Minor hypothesis 1 is accepted, that is, there is a relationship between risk perception and decision making to vaccinate. The correlation coefficient is positive, meaning that the more subjects perceive themselves to be at risk for contracting COVID-19, the higher the probability of the subject deciding to receive vaccination, and vice versa.

The correlation between trust in the government and vaccine taking decision making was tested using non-parametric statistics. The results of the Spearman correlation analysis produced a correlation coefficient $(r)$ of .436 with a significance level of $p=.000$ $(p<.01)$. this shows that there is a very significant positive correlation between trust in the government and vaccine taking decision making. With that, the minor hypothesis 2 is accepted, there is a correlation between trust in the government and the decision to vaccinate. The correlation coefficient is positive, so the higher the subject's trust in the government, the higher the probability of the subject deciding to receive vaccination, and vice versa.

To test the major hypothesis, multiple correlation tests were conducted. Based on the results of the multiple correlation test, it was found that the significance level was $p=.000$ $(p<.05)$ with a correlation coefficient of .511. This means that the major hypothesis is accepted, that there is a simultaneous correlation between risk perception and trust in the government in making decisions to vaccinate. Meanwhile, the degree of the 
correlation between perceived risk and trust in the government towards the decision to vaccinate is in the moderate category.

\subsection{Discussion}

The results of statistical tests indicate that the major hypothesis is accepted. This is in accordance with the research conducted by $([12,22])$ that perceived risk and trust in government have a correlation with decision making for vaccines. The correlation is at a moderate level, meaning that there are other factors that influence the relationship between the three variables simultaneously.

In the verification of minor hypothesis 1 which examines the relationship between risk perception and vaccination taking, there is a low significant relationship. In accordance with research findings [23] which found that people who are willing to vaccinate are people who perceive themselves to be at high risk of disease. In the descriptive analysis, it was also found that $96.7 \%$ of the respondents in this study perceive themselves to be at high risk for COVID-19 transmission. Similarly, there were $92.4 \%$ of subjects who were willing to vaccinate. The low association may be influenced by factors other than those studied here, namely unfamiliarity and the long-term impact of vaccination [23, 24].

Analysis of the partial relationship between trust in the government and vaccine acceptance shows a significant with a moderate level of correlation. The study supports the findings of the study of [25] [26] and [12], who found that trust in government was one of the factors that influenced individuals to vaccinate. The factors that influence trust in the government are self-awareness, benefits and risk perceptions of COVID19 transmission [27]. On the other hand, the delivery of inaccurate and inconsistent information will affects public trust in the government $[12,26]$.

The limitation of this research is that the survey distribution time is short, so the subjects only come from 9 provinces in Indonesia. In addition, the majority age range is in early adulthood. In conclusion, Indonesian people have a high risk perception of Covid-19 transmission and at the same time trust in the government is also high, these two variables have a relationship with a high willingness to vaccinate. Even so, the relationship between these three variables is in the moderate and low level, either partially or simultaneously. So for other researchers if they want to raise this phenomenon, they can add other variables that affect the relationship between variables getting stronger. In addition, a more in-depth data analysis can be carried out so that a more complete conclusion can be made regarding vaccination-related behavior. Suggestions for the 
government are to provide more complete and consistent information related to the pandemic to maintain public trust.

\section{References}

[1] Winastya KP. Kilas balik pertama kali kasus Covid-19 muncul di Rl, Diumumkan Langsung Presiden. Merdeka.Com. 2021 March 2. Available from: https://www.merdeka.com/trending/kilas-balik-pertama-kali-kasus-covid-19-munculdi-ri-diumumkan-langsung-presiden.html

[2] Peta Sebaran COVID-19. Covid19.Go.Id. 2021 March 1. Available from: https://covid19.go.id/peta-sebaran-covid19

[3] Ophinni Y, Hasibuan AS Widhani A, et al. COVID-19 vaccines: Current status and implication for use in Indonesia. Acta Medica Indonesiana. 2020;52(4):388.

[4] Program vaksinasi COVID-19 mulai dilakukan, presiden orang pertama penerima suntikan vaksin COVID-19. Direktorat Jendral P2P. 2021 January 13. Available from: http://p2p.kemkes.go.id/program-vaksinasi-covid-19-mulai-dilakukan-presidenorang-pertama-penerima-suntikan-vaksin-covid-19/

[5] WHO. COVID-19 vaccine acceptance survey in Indonesia-2020. Jakarta: Kementrian Kesehatan Republik Indonesia. 2020 November. Available from : https://covid19.go.id/storage/app/media/Hasil\%20Kajian/2020/November/vaccineacceptance-survey-en-12-11-2020final.pdf

[6] Allen JD, Othus MKD, Shelton RC et al. Parental decision making about the HPV Vaccine. Cancer Epidemiology Biomarkers \& Prevention. 2010;19(9):2187-2198. https://doi.org/10.1158/1055-9965.EPI-10-0217

[7] Shahrabani S, Benzion U, Yom Din G. Factors affecting nurses' decision to get the flu vaccine. The European Journal of Health Economics. 2009;10(2):227-231. https://doi.org/10.1007/s10198-008-0124-3

[8] Cheng P-J, Huang S-Y, Shaw S-W, et al. Factors influencing women's decisions regarding pertussis vaccine: A decision-making study in the Postpartum Pertussis Immunization Program of a teaching hospital in Taiwan. Vaccine. 2010;28(34):56415647. https://doi.org/10.1016/j.vaccine.2010.05.078

[9] Grantz KH, Claudot P, Kambala M, et al. Factors influencing participation in an Ebola vaccine trial among front-line workers in Guinea. Vaccine. 2019;37(48):7165-7170. https://doi.org/10.1016/j.vaccine.2019.09.094

[10] Marlow LAV, Waller J, Wardle J. Trust and experience as predictors of HPV vaccine acceptance. Human Vaccines. 2007;3(5):171-175. https://doi.org/10.4161/hv.3.5.4310 
[11] Suhanti IY, Noorrizki RD, Pambudi KS. Risk perception of Covid 19. KnE Social Sciences. Malang: International Conference Psychology. 2021:139-144. https://doi.org/10.18502/kss.v4i15.8197

[12] Van der Weerd W, Timmermans DR, Beaujean DJ, Oudhoff J, van Steenbergen JE. Monitoring the level of government trust, risk perception and intention of the general public to adopt protective measures during the influenza $A(\mathrm{H} 1 \mathrm{~N} 1)$ pandemic in the Netherlands. BMC Public Health. 2011;11(1):575. https://doi.org/10.1186/1471-2458-11575

[13] Casiday RE. Risk and trust in vaccine decision making. Durham Anthropology Journal. 2005;13(1):1-10.

[14] Danchin MH, Costa-Pinto J, Attwell K, et al. Vaccine decision-making begins in pregnancy: Correlation between vaccine concerns, intentions and maternal vaccination with subsequent childhood vaccine uptake. Vaccine. 2018;36(44):64736479.

[15] Glanz K, Rimer BK, Viswanath K. Health behavior and health education: Theory, research, and practice. San Francisco:John Wiley \& Sons; 2008.

[16] Hughes CC, Jones AL, Feemster KA, Fiks AG. HPV vaccine decision making in pediatric primary care: A semi-structured interview study. BMC Pediatrics. 2011;11(1):19.

[17] Jackson C, Cheater FM, Harrison W, et al. Randomised cluster trial to support informed parental decision-making for the MMR vaccine. BMC Public Health. 2011;11(1):475. https://doi.org/10.1186/1471-2458-11-475

[18] Serpell L, Green J. Parental decision-making in childhood vaccination. Vaccine. 2006;24(19):4041-4046. https://doi.org/10.1016/j.vaccine.2006.02.037

[19] Sturm LA, Mays RM, Zimet GD. Parental beliefs and decision making about child and adolescent immunization: From polio to sexually transmitted infections. Journal of Developmental \& Behavioral Pediatrics. 2005;26(6):441-452.

[20] Dryhurst S, Schneider CR, Kerr J, et al. Risk perceptions of COVID19 around the world. Journal of Risk Research. 2020;23(7-8):994-1006. https://doi.org/10.1080/13669877.2020.1758193

[21] Hoogink J, Verelst F, Kessels R, et al. Preferential differences in vaccination decisionmaking for oneself or one's child in The Netherlands: A discrete choice experiment. BMC Public Health. 2020;20(1):828. https://doi.org/10.1186/s12889-020-08844-w

[22] Hobson-West P. Understanding vaccination resistance: Moving beyond risk. Health, Risk \& Society. 2003;5(3):273-283. https://doi.org/10.1080/13698570310001606978 
[23] Freimuth VS, Jamison A, Hancock G, Musa D, Hilyard K, Quinn SC. The role of risk perception in flu vaccine behavior among African-American and white adults in the United States. Risk Analysis. 2017;37(11):2150-2163. https://doi.org/10.1111/risa.12790

[24] Bond L, Nolan T. Making sense of perceptions of risk of diseases and vaccinations: A qualitative study combining models of health beliefs, decision-making and risk perception. BMC Public Health. 2011;11(1):943. https://doi.org/10.1186/1471-2458-11-943

[25] Han $Q$, Zheng B, Cristea $M$, et al. Trust in government and its associations with health behaviour and prosocial behaviour during the COVID-19 pandemic. A cross-sectional and longitudinal study. Psychological Medicine, 1-32. 2020. https://doi.org/10.31234/osf.io/p5gns

[26] Soares P, Rocha JV, Moniz M, et al. Factors associated with COVID-19 vaccine hesitancy. Vaccines. 2021;9(3):300. https://doi.org/10.3390/vaccines9030300

[27] Fathimah AF, Al-Islami MF, Gustriani T, et al. Kepatuhan masyarakat terhadap pemerintah selama pandemi: Studi eksplorasi dengan pendekatan psikologi indigenous. Psikobuletin: Buletin Ilmiah Psikologi. 2021;2(1):15-22. https://doi.org/10.24014/pib.v2i1.11703 